\title{
Information Technology and Bilateral FDI: Theory and Evidence
}

\author{
Bang Nam Jeon \\ Drexel University \\ Linghui Tang \\ The University of Southern Mississippi \\ Lei Zhu \\ Drexel University
}

\begin{abstract}
This paper investigates the impact of communication cost on the FDI activities of multinational corporations (MNCs). First, we provide a theoretical foundation for a gravity-type FDI model, which shows that physical distance and communication technology are important determinants of FDI activities. Second, we apply the ITaugmented gravity model to bilateral FDI data for a total of 47 OECD and nonOECD countries from 1980 to 1997 and find that distance is negatively related to inward FDI stocks while the growth of IT, measured by teledensity and celldensity, has encouraged FDI significantly. The impact is found to be more prominent on FDI from $G 7$ countries to OECD countries, than to non-OECD countries, and more prominent in the 1990s than in the 1980s. Moreover, IT plays a more effective role by reducing communication cost when distance is beyond a threshold range.
\end{abstract}

\footnotetext{
*Correspondence address: Bang Nam Jeon, Department of Economics and International Business, Bennett S. LeBow College of Business, Drexel University, Philadelphia, PA 19104, USA, Tel: +1-215-895-2125, Email: jeonbana@drexel.edu; Linghui Tang, Department of Economics, Finance, and International Business, College of Business and Economic Development, The University of Southern Mississippi, Hattiesburg, MS 39406, USA, Tel: +1-601-266-6612, E-mail: linghui.tang@usm.edu, Lei Zhu, Department of Economics and International Business, Bennett S. LeBow College of Business, Drexel University, Philadelphia, PA 19104, USA, Tel: +1-215-895-2123, E-mail: 1z24@drexel.edu.

(C2005-Center for International Economics, Sejong Institution, All Rights Reserved.
} 
- JEL Classifications: F21, F23

- Key words: Communication cost, FDI, Distance

\section{Introduction}

The existing literature on multinational corporations (MNCs) has long recognized the importance of headquarter services, which provide knowledge-based and knowledge-generating activities (Markusen, 1984 and 1995, Markusen and Venebles 1998). Examples of headquarter services include $R \& D$, financial management, technology know-how, marketing skills, and so on. It is assumed that these intangible assets can be transferred and shared by multiple production facilities with little cost. In other words, the existing theory suggests that distance does not matter for the emergence of MNCs, especially for horizontal MNCs when there is no trading of goods. However, empirical evidence almost always revealed that physical distance is negatively and significantly related to multinational activities even after controlling for trade and investment costs (Carr et al. 2001).

The purpose of this paper is to offer a new interpretation of the role of distance in the FDI activities by MNCs. Unlike the traditional view, we consider distance to represent the communication cost of moving information and knowledge rather than the cost of moving goods for MNCs. As we observe in practice, the transfer of headquarter services through the travel of key personnel or post mail can be costly. The development of modern information technology (IT) provides a more efficient way for sharing information and knowledge within MNCs.

Following the communication cost and international trade model proposed by Harris (1995) and then further developed by Kikuchi and Ichikawa (2002) and Kikuchi (2003), we consider the communication cost for FDI to have two components. First, it is proportional to the distance between the home and host countries with the coefficient determined by the state of IT in both countries. The second part of the communication cost includes the investment of building a communication network. Our model provides a theoretical justification for using a gravity equation for FDI. That is, multinational activities decrease with distance while increasing with the development of IT and the economic sizes of the home and host countries.

The empirical section of this paper utilizes the recently available bilateral FDI stock data for 27 OECD and 20 non-OECD countries between 1980 and 1997. 
Applying an IT-augmented gravity model, we find that the relationship between distance and inward FDI stocks is always negative, which is similar to international trade. Most importantly, we find that the increasing density of telephone lines and wireless phones encourage bilateral FDI for all pairs of countries. The impact of IT is found to be greater for FDI from G7 to OECD countries than that to non-OECD countries. Meanwhile, the impact of IT on FDI is more prominent and for FDI during the 1990s than the 1980s. In addition, IT performs a more important role in reducing the perceived distance when the distance between two countries is greater than a threshold range.

The paper is organized as follows. Section 2 presents the theoretical framework of FDI with communication cost. The empirical test and findings are reported in Section 3. Section 4 provides the conclusions.

\section{The Theoretical Framework}

This section develops a MNC model with communication costs in the spirit of the multinational theory developed by Helpman and Krugman (1980), Markusen and Venables (1998), and Ethier (1986). For simplicity, we assume there is only one factor for production: labor. All costs are measured in terms of labor units hereafter. To emphasize the importance of the knowledge-capital model, multinational firms in country $i(=1,2)$ have to decide the level of investment in headquarter services, represented by $h_{i}$, in the first stage. Firms will choose output for production in the second stage.

The central assumption of our model is that the transfer of headquarter services to different locations requires communication cost, $C C_{i}$. The communication cost has two parts. The first part of $C C_{i}$ represents the traveling costs of key multinational personnel and the time and expenses needed for exchanging information through all possible channels. In other words, it is proportional to the distance between the two countries $(D)$ with coefficient $c_{i}\left(T_{i}, T_{j}\right)$, where $T_{i}$ and $T_{j}$ $(i \neq j=1,2)$ represent the state of information technology in country $i$ and country $j$, respectively, and $\partial c_{i} / \partial T_{i}, \partial c_{i} / \partial c_{j}<0$. The reason that the technology parameter not only depends on the home country's technology but also the foreign country's technology is due to the joint provision of service requirement for mail and telecommunication services ${ }^{1}$.

${ }^{1}$ See Tang (2003) for a discussion of the institutional arrangement for international communications. 
The second part of the communication cost is what firms have to pay to be connected to the global network. We assume that the cost to build a communication network infrastructure for country $i$ is proportional to the product of population of in country i and country j, $L_{i} L_{j}$, and the headquarter services $h_{i}$. Similar to Harris (1995), it is assumed that parent firms share the home country's infrastructure cost equally. If the number of multinational firms headquartered in country i is $m_{i}$, we have the total communication cost for a multinational firm in country $i$ as follows.

$$
C C_{i}=c_{i}\left(T_{i}, T_{j}\right) D+\alpha L_{i} L_{j} h_{i} / m_{i}
$$

According to equation (1), $C C_{i}$ is an endogenous variable: it is not only determined by headquarter services $h_{i}$, another endogenous variable, but also by the number of multinational firms.

Consider a general equilibrium model with only one sector producing differentiated goods. Both the home and foreign country's national firms are assumed to have the same fixed and marginal production cost, denoted by $f$ and $g$, respectively. Furthermore, multinational firms have the same fixed cost as national firms but a different marginal production cost $\gamma_{m_{i}}\left(h_{i}\right)$, which is determined by the level of headquarter services and $\gamma_{m_{i}}^{\prime}\left(h_{i}\right)<0$. To abstract from the transportation cost and tariffs associated with international trade, the differentiated goods are assumed to be non-tradable.

Now, the cost to produce $x$ units of a differentiated good in terms of labor units $l_{i, n_{i}}$ and $l_{i, m_{i}}$ by a national and a multinational firm in country i, respectively, can be written as

$$
\begin{gathered}
l_{i, n_{i}}=f+\gamma x_{i, n_{i}} \\
l_{i, m_{i}}=2 f+h_{i}+\gamma_{m_{i}}\left(h_{i}\right) x_{i, m_{i}}+\gamma_{m_{i}}\left(h_{i}\right) x_{j, m_{i}}+C C_{i}
\end{gathered}
$$

In equations (2) and (3), $x_{i, n_{i}}$ is the output of a national firm in country $i$, while $x_{i, m_{i}}$ and $x_{j, m_{i}}(\mathrm{i} \neq \mathrm{j})$ represent the outputs of a multinational firm in the home (i) and foreign country $(\mathrm{j})$, respectively.

Suppose that factor price is equalized and the relative wage rate is normalized to one. Then, the profit functions for a national and a multinational firm in country $i$ are as follows:

$$
\begin{gathered}
\pi_{i, n_{i}}=P_{i, n_{i}} \cdot x_{i, n_{i}}-\left(f+\gamma x_{i, n_{i}}\right) \\
\pi_{i, m_{i}}=\left[P_{i, m_{i}} \cdot x_{i, m_{i}}-\left(f+h_{i}+\gamma_{m_{i}}\left(h_{i}\right) x_{i, m_{i}}\right)-C C_{i}\right]+\left[P_{j, m_{i}} x_{j, m_{i}}-\left(f+\gamma_{m_{i}}\left(h_{i}\right) x_{j, m_{i}}\right)\right]
\end{gathered}
$$


In equations (4) and (5), $P_{i, n_{i}}, P_{i, m_{i}}$ and $P_{j, m_{i}}$ are the prices of goods sold by a national and a multinational firm from country $i$ in the home and foreign country, respectively.

Now, let $d_{i k}$ represent a typical consumer k's consumption of goods in country i. With $n_{i}$ number of national firms and $\left(m_{i}+m_{j}\right)$ number of multinational firms, the representative utility function of consumers is

$$
U_{i k}=\sum_{i k=1}^{n_{i}+m_{i}+m_{j}} d_{i k}^{\beta}
$$

Through utility maximization, it is easy to show that the inverse demand functions in both the home and foreign country is: $P_{i k}=\lambda_{i}^{-1} \beta d_{i k}{ }^{\beta-1}$, where $\lambda_{i}$ is the shadow price on the budget constraint. By plugging in the equilibrium price into equations (4) and (5), we can solve for the profit-maximizing prices, given the level of headquarter services in the second stage. It can be shown that both the home and foreign country's national firms charge the same price, i.e. $P_{i, n_{i}}=\beta^{-1} \gamma$ while multinational firms have the same price in both the home and foreign country, i.e. $P_{i, m_{i}}=P_{j, m_{i}}=\beta^{-1} \gamma_{m_{i}}\left(h_{i}\right)$.

Using zero profit and utility maximization conditions, we have the following equilibrium conditions regarding the outputs of national and multinational firms.

$$
\begin{gathered}
x_{i, n_{i}}=f^{\prime} \gamma\left(\beta^{-1}-1\right) \\
x_{i, m_{i}}=x_{j, m_{i}}=\left[\gamma_{m_{i}}\left(h_{i}\right) / \gamma\right]^{1 /(\beta-1)}\left[f^{\prime} \gamma\left(\beta^{-1}-1\right)\right] \\
x_{i, m_{i}}+x_{j, m_{i}}=\left(2 f+h_{i}+C C_{i}\right) /\left[\gamma_{m_{i}}\left(h_{i}\right)\left(\beta^{-1}-1\right)\right]
\end{gathered}
$$

Then, multinational firms can figure out the profit-maximizing headquarter services, $h_{i}^{*}$. For simplicity, let $\gamma_{m_{i}}\left(h_{i}\right)=\gamma-\delta h_{i}, \delta>0$. Using backward induction, the optimal level of headquarter services is

$$
h_{i}^{*}=\gamma^{\prime} \delta-\left(\gamma^{\prime} \delta\right)\left[\left(1+\alpha L_{i} L_{j} / m_{i}\right) \gamma^{\prime}(2 f t \delta)\right]^{\beta-1}
$$

where $t=\beta /(1-\beta)$

Using equations (8)-(10), the equilibrium number of multinational firms is ${ }^{2}$

$$
m_{i}^{*}=\frac{\alpha\left[\left(\gamma^{\prime} \delta\right)^{\beta} \beta k-\gamma^{\prime} \delta\right] L_{i} L_{j}}{2 f+c_{i}\left(T_{i}, T_{j}\right) D+\left(\gamma^{\prime} \delta\right)-\left(\gamma^{\prime} \delta\right)^{\beta} k}
$$

\footnotetext{
${ }^{2}$ We have used Taylor expansion to simplify the non-linear equation to derive the result in equation (11).
} 
where $k=2 f^{1-\beta} t^{-\beta}(1-\beta)^{-1}$

The implications we can derive from equation (11) are straightforward. First, the distance between two countries, $D$, is negatively related to the equilibrium number of multinational firms, $m_{i}^{*}$, which is an indicator of FDI activities. The reason that the greater the distances the less MNCs is due to the existence of the communication cost for transferring headquarter services, which increases with the physical distance between two countries. Second, the technology parameter $c_{i}\left(T_{i}, T_{j}\right)$ is negatively related to FDI activities. In other words, the development of IT in either the home or foreign country will shrink the perceived physical distance between two nations and encourage FDI. Overall, the distance-related communication cost is inversely related to the number of multinational firms. Third, the number of MNcs or bilateral FDI activities is positively related to the product of two countries' population (or economicsize), which is consistent with the prediction of the gravity equation.

The theoretical framework developed in this section provides a foundation for a gravity-type FDI model. That is, bilateral FDI activity is positively related to the economic sizes of the home and host countries, while it is negatively related to physical distance between the two countries, discounted by the development of IT.

\section{Empirical Test}

In this section, we use an IT-augmented gravity equation, as justified as equation (11), to empirically test the impact of IT and distance on FDI. Although the gravity model is the most popular empirical framework for bilateral international trade, it has not been used much for FDI due to the lack of bilateral FDI data. Using FDI and MNC data for the U.S. and Asian countries, Brainard (1997), Blonigen and Davies (2000), and Stone and Jeon (2000) all find the gravity model to be very successful in explaining multinational activities. More specifically, we have

$$
\begin{aligned}
& \log F D I_{i-j, t}= \\
& \alpha_{t}+\beta_{1} \log G D P_{i, t}+\beta_{2} \log G D P_{j, t}+\beta_{3} \log {\text { Dis } \tan c e_{i-j}}+\beta_{4} \log I T_{i-j, t} \\
& \quad+\beta_{5} \log I T_{i-j, t} * \log \text { Dis } \tan c e_{i-j}+\beta_{6} \text { openTrade }_{j, t}+\beta_{7} \text { openFDI }_{j, t} \\
& \quad+\beta_{8} \text { Language }_{i-j}+\beta_{9} \text { Trety }_{i-j, t}+\beta_{10} \text { EU }_{i-j}+\beta_{11} N A F T A_{i-j}+\varepsilon_{i, t}
\end{aligned}
$$


In equation (12), $\log F D I_{i-j, t}$ is the log of FDI stocks in millions of US dollars from country i to country $\mathrm{j}$ at time t. $\log G D P_{i, t}$ and $\log G D P_{j, t}$ are the $\operatorname{logs}$ of GDP in the home and host countries, respectively. Since FDI is positively related to the home and host countries' economic sizes, the coefficients of both GDP variables are expected to be positive. $\log$ Dis $\tan c e_{i-j}$ is the $\log$ of distance in kilometers between the capital cities of country $i$ and country $j$. As our theory suggests, the farther away the two countries are, the higher the communication cost and then the lower the FDI. Therefore, $\beta_{3}$ should be negative.

$\log I T_{i-j, t}$ is an indicator of the sophistication of the IT network between the home and host countries at time t. The IT variables are measured by the teledensity index, the number of telephone lines per 100 persons, and the celldensity index, the number of wireless phones per 100 persons in each country. The product of the teledensity (celldensity) for the host and home countries $\left(\log I T_{i-j, t}{ }^{*} \log I T_{i-j, t}\right)$ is used to measure the development of IT over time because effective communications require an advancement of IT from both ends. In addition, we also combine teledensity and celldensity as a another proxy of IT development since wireless technology has provided a fast and inexpensive way for many countries to catch up in building communication infrastructure. To be consistent with our theory, we expect $\beta_{4}$ to be positive. That is, the higher the IT adoption rate for both countries, the more FDI from the home country to the host country. We also include an interactive term of the IT variable and the distance in the regression to test the hypothesis that the development of IT encourages FDI by reducing the communication cost. Without the interactive term, the impact of distance on bilateral FDI inward stocks is measured by $\partial \log F D I / \partial \log D i s \tan c e=\beta_{3}$. When incorporating the interactive term, the impact is measured by $(\partial \log F D I /$ $\partial \log$ Distance $=\beta_{3}+\beta_{5}\left(\log I T_{i-j}\right)=\beta_{3}$. We expect $\beta_{5}$ to be positive or a small negative, since we hypothesize that the physical distance will be reduced by the enhancement of IT so that and $\beta_{3}<\beta_{3}^{\prime}$.

Finally, some traditional control variables are added into the IT-augmented gravity equation. openTrade $e_{j, t}$ is the host country's imports as a percentage of the GDP. This variable controls for the host country's openness to trade. A high import to GDP ratio implies that the host country has less restrictions on imports. According to the "tariff-jumping" FDI theory, less FDI activities should follow. However, if FDI and trade are complements, as found by Lipsey and Weiss (1981 and 1984), the coefficient $\beta_{6}$ should be positive openFDI $I_{j, i}$. measures a country's openness to FDI, which is calculated as the ratio of the host country's inward FDI flows to its 
GDP. Everything else being the same, a better investment environment will encourage FDI from country $\mathrm{i}$ to country $\mathrm{j}$. In addition, four dummy variables Language $_{i-j}$, Treaty ${ }_{i-j, t}, E U_{i-j}$ and $N A F T A_{i-j}$ are included. Language $e_{i-j}$ indicates whether or not the two countries speak the same language. Countries speaking the same language can more easily communicate with each other and are supposed to have higher FDI activities. Treaty $i_{i-j, t}$ shows whether or not country $i$ and $j$ have an agreement on taxation of income and capital at year $t$. It is believed that a bilateral tax agreement provides a favorable environment for FDI activities. $E U_{i-j}$ and $N_{A F T A}{ }_{i-j}$ suggests whether or not country $\mathrm{i}$ and $\mathrm{j}$ are members of the European Union and NAFTA (after 1994), respectively. They capture the effect of the regional economic integration on FDI movement.

Given the availability of the data, our sample includes 27 OECD countries and 20 non-OECD countries from 1980 to 1997 . Since G7 countries are the major source of FDI activity, we focus our study on the FDI from G7 countries to all other countries. The data sources and the definitions of the variables used in this study are described in the Appendix. The descriptive statistics of all variables are reported in Table 1.

Table 2 presents the estimation results for inward FDI stocks using OLS regression. ${ }^{3}$ All regressions take the time fixed effect into account and we use the robust estimators of variance that allow for correlation in repeated observations for the same pairs of countries. In column (1) - (4), we run regressions with the hostcountry fixed effect. We first use teledensity as a proxy of IT development in column (1). Then we combine teledensity and celldensity as an alternative proxy for the IT variable in column (3). The interactive term of the IT variable and distance are included in columns (2) and (4). In columns (5) - (8), the regressions control for the country-pair fixed effect, producing higher $R^{2}$. The coefficients of the year and country dummies are not shown in the table due to space constraints.

As we can see, the coefficient of distance is always negative and significant. The distance elasticity of inward FDI stock is in the range of -0.79 to $-0.84 .{ }^{4}$ This is consistent with our communication cost assumption for managing multinationals. The communication costs for sharing headquarter services increase with the

\footnotetext{
${ }^{3}$ We use FDI stocks rather than FDI flows because there were many negative and zero numbers in the FDI flow data. The estimation results using FDI flows with a smaller number of observations were not much different from the results using the FDI stocks.

${ }^{4}$ Distance is dropped in the country-pair fixed effect model, since it does not vary over time. For similar reasons, Language and $E U$ dummies are dropped as well.
} 
Table 1. Descriptive Statistics of Variables

\begin{tabular}{|c|c|c|c|c|c|}
\hline Variable & Description & Mean & Std. Dev. & Min & Max \\
\hline $\log G D O_{j}$ & $\log$ of GDP in the host country & 4.7417 & 1.3656 & 0.9821 & 9.0240 \\
\hline $\log$ Distance $_{i-j}$ & $\begin{array}{l}\text { log of distance between the capital } \\
\text { cities of country } i \text { and country } j\end{array}$ & 8.4583 & 1.0184 & 5.2743 & 9.8526 \\
\hline $\log I T_{i-j}$ & Log of (teledencity +celldensity) in the host country & 10.6382 & 5.6472 & -5.8107 & 21.9667 \\
\hline openTrade $_{j}$ & openness to trade in host country & 35.4884 & 30.2679 & 4.6313 & 223.6470 \\
\hline openFDI $I_{j}$ & openness to FDI in host country & 1.4656 & 2.0272 & -0.8424 & 15.2025 \\
\hline \multirow{2}{*}{$\begin{array}{l}\log I T_{i-j}{ }^{*} \\
\log \text { Dis } \tan c e\end{array}$} & the interaction term of logIT (teledensity) and logDistance or & 85.1339 & 45.1088 & -54.1536 & 172.6459 \\
\hline & the interaction term of logIT (teledensity+celldensity) and logDistance & 88.2520 & 47.8820 & -54.1536 & 199.6993 \\
\hline
\end{tabular}

Note: FDI, GDP are in billions of US dollars. Distance is in kilometers. Teledensity is the number of telephone lines per 100 residents and celldensity is the number of cell phones per 100 residents. OpenTrade and openFDI are all in percentages. 
Table 2. Information Technology and Inward FDI Stocks

\begin{tabular}{|c|c|c|c|c|c|c|c|c|}
\hline & \multicolumn{4}{|c|}{ With host dummy } & \multicolumn{4}{|c|}{ With country pair dummy } \\
\hline & $\begin{array}{c}\mathrm{IT}=\text { tele } \\
\text { (1) }\end{array}$ & $\begin{array}{l}\mathrm{IT}=\text { tele } \\
(2)\end{array}$ & $\begin{array}{c}\mathrm{IT}=\text { tele }+ \text { cell } \\
\text { (3) }\end{array}$ & $\begin{array}{c}\mathrm{IT}=\text { tele }+ \text { cell } \\
\text { (4) }\end{array}$ & $\begin{array}{c}\mathrm{IT}=\text { tele } \\
(5)\end{array}$ & $\begin{array}{l}\mathrm{IT}=\text { tele } \\
(6)\end{array}$ & $\mathrm{IT}=$ tele + cell $(7)$ & $\mathrm{IT}=$ tele + cell $(8)$ \\
\hline $\operatorname{logGDP}_{j, t}$ & $\begin{array}{l}0.1977 \\
(1.10)\end{array}$ & $\begin{array}{l}0.1973 \\
(1.09)\end{array}$ & $\begin{array}{r}0.2651 \\
(1.48)\end{array}$ & $\begin{array}{l}0.2657 \\
(1.48)\end{array}$ & $\begin{array}{c}0.4367^{* * * *} \\
(2.86)\end{array}$ & $\begin{array}{c}0.4177^{* * * *} \\
(2.80)\end{array}$ & $\begin{array}{c}0.5057 * * * \\
(3.31)\end{array}$ & $\begin{array}{c}0.4965 * * * \\
(3.32)\end{array}$ \\
\hline $\log \mathrm{GDP}_{i, t}$ & $\begin{array}{c}1.2253^{* * * *} \\
(17.60)\end{array}$ & $\begin{array}{c}1.2257 * * * \\
(17.60)\end{array}$ & $\begin{array}{c}1.1848 * * * \\
(16.86)\end{array}$ & $\begin{array}{c}1.1849 * * * \\
(16.87)\end{array}$ & $\begin{array}{l}0.6455^{* * * *} \\
\quad(2.75)\end{array}$ & $\begin{array}{c}0.5896^{* * *} \\
(2.54)\end{array}$ & $\begin{array}{c}0.6248 * * * \\
(2.59)\end{array}$ & $\begin{array}{c}0.6038 * * \\
(2.52)\end{array}$ \\
\hline $\operatorname{logDistance}_{i-j}$ & $\begin{array}{c}-0.7946 * * * \\
(-8.23)\end{array}$ & $\begin{array}{c}-0.8388 * * * \\
(-3.60)\end{array}$ & $\begin{array}{c}-0.8273 * * * \\
(-8.54)\end{array}$ & $\begin{array}{c}-0.8041 * * * \\
(-3.58)\end{array}$ & & & & \\
\hline $\log \mathrm{IT}_{i, t} * \log \mathrm{IT}_{j, t}$ & $\begin{array}{l}0.3127 * * * \\
\quad(5.24)\end{array}$ & $\begin{array}{c}0.2815^{*} \\
(1.75)\end{array}$ & $\begin{array}{c}0.3521 * * * \\
\quad(5.44)\end{array}$ & $\begin{array}{c}0.3682 * * \\
(2.31)\end{array}$ & $\begin{array}{l}0.2105^{* * * *} \\
\quad(4.45)\end{array}$ & $\begin{array}{c}0.8873 * * * \\
\quad(3.80)\end{array}$ & $\begin{array}{c}0.2165 * * * \\
(4.33)\end{array}$ & $\begin{array}{c}0.7324 * * * \\
(3.79)\end{array}$ \\
\hline $\operatorname{logIT} * \log$ Distance & & $\begin{array}{l}0.0036 \\
(0.22)\end{array}$ & & $\begin{array}{c}-0.0018 \\
(-0.12)\end{array}$ & & $\begin{array}{c}-0.0760 * * * \\
(-3.13)\end{array}$ & & $\begin{array}{c}-0.0564 * * * \\
(-2.99)\end{array}$ \\
\hline openTrade $_{j, t}$ & $\begin{array}{c}-0.0179 * * * \\
(-3.22)\end{array}$ & $\begin{array}{c}-0.0181 * * * \\
(-3.25)\end{array}$ & $\begin{array}{c}-0.0213 * * * \\
(-3.58)\end{array}$ & $\begin{array}{c}-0.0212 * * * \\
(-3.61)\end{array}$ & $\begin{array}{c}-0.0135 * * * \\
(-2.70)\end{array}$ & $\begin{array}{c}-0.0113^{* *} \\
(-2.48)\end{array}$ & $\begin{array}{c}-0.0150 * * * \\
(-2.86)\end{array}$ & $\begin{array}{c}-0.0129 * * \\
(-2.72)\end{array}$ \\
\hline openFDI $_{j, t}$ & $\begin{array}{l}0.0871 * * * \\
(2.67)\end{array}$ & $\begin{array}{l}0.0874 * * * \\
(2.67)\end{array}$ & $\begin{array}{c}0.0818 * * \\
(2.47)\end{array}$ & $\begin{array}{c}0.0815^{* *} \\
(2.47)\end{array}$ & $\begin{array}{c}0.0938^{* * * *} \\
(2.95)\end{array}$ & $\begin{array}{c}0.0909 * * * \\
(3.03)\end{array}$ & $\begin{array}{c}0.0943 * * * \\
(2.92)\end{array}$ & $\begin{array}{c}0.0883 * * * \\
(2.87)\end{array}$ \\
\hline language & $\begin{array}{c}0.6494 * * * \\
(2.74)\end{array}$ & $\begin{array}{l}0.6512 * * * \\
\quad(2.74)\end{array}$ & $\begin{array}{c}0.6461 * * * \\
(2.72)\end{array}$ & $\begin{array}{l}0.6453 * * * \\
(2.71)\end{array}$ & & & & \\
\hline treaty & $\begin{array}{l}0.5079 * * * \\
\quad(3.28)\end{array}$ & $\begin{array}{l}0.5101 * * * \\
\quad(3.31)\end{array}$ & $\begin{array}{l}0.5152 * * * \\
\quad(3.33)\end{array}$ & $\begin{array}{l}0.5139 * * * \\
\quad(3.33)\end{array}$ & $\begin{array}{c}-0.0184 \\
(-0.05)\end{array}$ & $\begin{array}{l}0.0440 \\
(0.12)\end{array}$ & $\begin{array}{c}-0.0332 \\
(-0.09)\end{array}$ & $\begin{array}{c}0.0141 \\
(0.04)\end{array}$ \\
\hline EU & $\begin{array}{l}-0.1334 \\
(-0.47)\end{array}$ & $\begin{array}{c}-0.1207 \\
(-0.42)\end{array}$ & $\begin{array}{c}-0.1496 \\
(-0.52)\end{array}$ & $\begin{array}{c}-0.1557 \\
(-0.54)\end{array}$ & & & & \\
\hline NAFTA & $\begin{array}{c}-0.1611 \\
(-0.42)\end{array}$ & $\begin{array}{c}-0.1528 \\
(-0.40)\end{array}$ & $\begin{array}{c}-0.1581 \\
(-0.36)\end{array}$ & $\begin{array}{c}-0.1642 \\
(-0.38)\end{array}$ & $\begin{array}{c}-0.0077 \\
(-0.04)\end{array}$ & $\begin{array}{c}-0.1697 \\
(-0.80)\end{array}$ & $\begin{array}{c}0.0547 \\
(0.28)\end{array}$ & $\begin{array}{c}-0.1082 \\
(-0.44)\end{array}$ \\
\hline No. of observation & 4232 & 4232 & 4014 & 4014 & 4232 & 4232 & 4014 & 4014 \\
\hline R-square & 0.729 & 0.729 & 0.731 & 0.731 & 0.904 & 0.906 & 0.905 & 0.907 \\
\hline
\end{tabular}

Note: ${ }^{*}, * * * *$ significant at the 10 per cent, 5 per cent and 1 per cent levels, respectively. 
distance between two countries. Hence, less FDI activity is expected. As expected, the coefficient of the interactive term is positive or small negative. We should note that after including the interactive term of IT variable and distance in columns (2) and (4), the overall elasticity of distance on FDI is $\beta_{3}+\beta_{5}\left(\log \mathrm{IT}_{i-j}\right)$. Given that the mean of $\log I T_{i-j, t}$ is 10.24 , the overall distance elasticity is -0.8019 and -0.8255 respectively. Based on the result in Table 2, it is not dovious wherther the development of IT has reduced the negative role of distance of FDI.

However, we find that the growth of IT for a country pair encourages FDI. The coefficient on the IT variable is always positive and statistically significant. More specifically, the coefficient on the IT variable is 0.217 in column (7) without the interactive term, while it ranges from 0.177 to 0.435 with the interactive term according to column (8). ${ }^{5}$ It implies that any one percent increase in the IT network will increase a country's inward FDI stocks by 0.18 to 0.44 percent.

To test the robustness of our results, we utilize sub-sample analysis using the country-pair fixed effect model, which produces a higher $R^{2}$ than the host-country only fixed effect. We first split the data into two groups: for FDI from G7 to OECD countries and from $\mathrm{G} 7$ to non-OECD countries. The results are reported in Table 3 . We find that the growth of teledensity and celldensity encourages more FDI from $\mathrm{G} 7$ to OECD countries than from $\mathrm{G} 7$ to non-OECD countries. For example, percent increase in the global telephone network will increase FDI inward stock by 0.83 for OECD countries while only by 0.17 for non-OECD countries. Similar results are found when aggregating teledensity and celldensity as a proxy of IT development.

Next, we divide the data into two time periods: the 1980s and the 1990s. As we can see in Table 4, the coefficient of the IT variable is not significant in the 1980s while it turns out to be very significant in the 1990 s, implying a more prominently favorable role of the development of IT in enhancing the FDI activities in the 1990s than in the 1980s. Even with the interactive term, the role of IT seems to be more prominent in the $1990 \mathrm{~s}^{6}$

An interesting finding is reported in Table 5 after we split the whole sample into two groups by distance. In columns (1) - (4), the distance between the capital cities

\footnotetext{
${ }^{5}$ The overall elasticity of IT on FDI is $\left(0.8613-0.0795^{*} \log\right.$ Distance). The range is calculated using minimum and maximum of $\log$ Distance, which is 5.27 and 9.85 respectively.

${ }^{6}$ Since all regressions in Tables 3 and 4 include country-pair and time dummies, distance is dropped as it does not vary over time. Consequently, we are unable to evaluate the change of the elasticity of distance with respect ot FDI when the interactive term of IT and distance is included.
} 
Table 3. IT and Inward FDI Stocks, G7 to OECD vs. non-OECD countries (with the country-pair fixed effect)

\begin{tabular}{|c|c|c|c|c|c|c|c|c|}
\hline & \multicolumn{4}{|c|}{ OECD countries } & \multicolumn{4}{|c|}{ Non-OECD countries } \\
\hline & $\begin{array}{c}\mathrm{IT}=\text { tele } \\
\text { (1) }\end{array}$ & $\begin{array}{c}\text { IT }=\text { tele } \\
\text { (2) }\end{array}$ & $\begin{array}{c}\mathrm{IT}=\text { tele }+ \text { cell } \\
\text { (3) }\end{array}$ & $\begin{array}{c}\mathrm{IT}=\text { tele }+ \text { cell } \\
\text { (4) }\end{array}$ & $\begin{array}{c}\text { IT }=\text { tele } \\
(5)\end{array}$ & $\begin{array}{c}\text { IT }=\text { tele } \\
(6)\end{array}$ & $\begin{array}{c}\text { IT }=\text { tele }+ \text { cell } \\
\text { (7) }\end{array}$ & $\begin{array}{c}\text { IT }=\text { tele }+ \text { cell } \\
(8)\end{array}$ \\
\hline $\operatorname{logGDP}_{\mathrm{j}, \mathrm{t}}$ & $\begin{array}{l}0.3458 \\
(1.05)\end{array}$ & $\begin{array}{l}0.3460 \\
(1.04)\end{array}$ & $\begin{array}{c}0.8346^{* *} \\
(2.48)\end{array}$ & $\begin{array}{c}0.7805^{* *} \\
(2.35)\end{array}$ & $\begin{array}{c}0.3127^{*} \\
(1.78)\end{array}$ & $\begin{array}{c}0.3169^{*} \\
(1.80)\end{array}$ & $\begin{array}{c}0.3289^{*} \\
(1.74)\end{array}$ & $\begin{array}{c}0.3365^{*} \\
(1.79)\end{array}$ \\
\hline $\operatorname{logGDP} P_{i, t}$ & $\begin{array}{c}0.7589 * * * \\
(2.88)\end{array}$ & $\begin{array}{c}0.7611 * * * \\
\quad(2.87)\end{array}$ & $\begin{array}{c}0.8655^{* * * *} \\
\quad(3.24)\end{array}$ & $\begin{array}{c}0.8810^{* * * *} \\
(3.28)\end{array}$ & $\begin{array}{c}0.6551^{*} \\
(2.88)\end{array}$ & $\begin{array}{c}0.5907^{*} \\
(1.70)\end{array}$ & $\begin{array}{c}0.6379^{*} \\
(1.67)\end{array}$ & $\begin{array}{l}0.5556 \\
(1.49)\end{array}$ \\
\hline $\log \mathrm{IT}_{\mathrm{i}, \mathrm{t}} * \log \mathrm{IT}_{\mathrm{j}, \mathrm{t}}$ & $\begin{array}{c}0.8346^{* * * *} \\
(6.24)\end{array}$ & $\begin{array}{c}0.8966^{* * * *} \\
(4.06)\end{array}$ & $\begin{array}{c}0.7402^{* * * *} \\
\quad(5.20)\end{array}$ & $\begin{array}{c}1.0629 * * * \\
(4.64)\end{array}$ & $\begin{array}{c}0.1735^{* * * *} \\
(3.36)\end{array}$ & $\begin{array}{l}0.3667 \\
(1.08)\end{array}$ & $\begin{array}{c}0.1449 * * * \\
(2.68)\end{array}$ & $\begin{array}{l}0.3867 \\
(1.31)\end{array}$ \\
\hline $\operatorname{logIT} * \log$ Distance & & $\begin{array}{c}-0.0086 \\
(-0.33)\end{array}$ & & $\begin{array}{c}-0.0392 * * \\
(-2.03)\end{array}$ & & $\begin{array}{c}-0.0220 \\
(-0.57)\end{array}$ & & $\begin{array}{c}-0.0276 \\
(-0.83)\end{array}$ \\
\hline openTrade $_{\mathrm{j}, \mathrm{t}}$ & $\begin{array}{c}-0.0255^{* *} \\
(-2.44)\end{array}$ & $\begin{array}{c}-0.0253^{* *} \\
(-2.41)\end{array}$ & $\begin{array}{c}-0.0228^{* *} \\
(-2.00)\end{array}$ & $\begin{array}{c}-0.0210^{*} \\
(-1.94)\end{array}$ & $\begin{array}{l}-0.0051 \\
(-1.23)\end{array}$ & $\begin{array}{c}-0.0048 \\
(-1.16)\end{array}$ & $\begin{array}{c}-0.0073^{*} \\
(-1.69)\end{array}$ & $\begin{array}{l}-0.0069 \\
(-1.60)\end{array}$ \\
\hline openFDI $_{\mathrm{j}, \mathrm{t}}$ & $\begin{array}{c}0.0985 * * \\
(2.25)\end{array}$ & $\begin{array}{c}0.0987 * * \\
(2.26)\end{array}$ & $\begin{array}{c}0.0905^{*} \\
(1.84)\end{array}$ & $\begin{array}{c}0.0858^{*} \\
(1.77)\end{array}$ & $\begin{array}{c}0.0532 * * \\
(2.51)\end{array}$ & $\begin{array}{c}0.0543 * * \\
(2.56)\end{array}$ & $\begin{array}{c}0.0610^{* * *} \\
(2.62)\end{array}$ & $\begin{array}{c}0.0624 * * * \\
(2.68)\end{array}$ \\
\hline treaty & $\begin{array}{c}0.3062 \\
(0.47)\end{array}$ & $\begin{array}{c}0.3296 \\
(0.49)\end{array}$ & $\begin{array}{c}0.4246 \\
(0.58)\end{array}$ & $\begin{array}{l}0.5357 \\
(0.73)\end{array}$ & $\begin{array}{c}-0.0610 \\
(-0.20)\end{array}$ & $\begin{array}{l}-0.0727 \\
(-0.23)\end{array}$ & $\begin{array}{c}-0.1135 \\
(-0.34)\end{array}$ & $\begin{array}{l}-0.1375 \\
(-0.40)\end{array}$ \\
\hline NAFTA & $\begin{array}{c}-0.0904 \\
(-0.49)\end{array}$ & $\begin{array}{c}-0.1125 \\
(-0.58)\end{array}$ & $\begin{array}{c}0.0276 \\
(0.19)\end{array}$ & $\begin{array}{l}0.1418 \\
(0.84)\end{array}$ & $\begin{array}{c}0.4260 * * \\
(2.15)\end{array}$ & $\begin{array}{c}0.3696 \\
(1.62)\end{array}$ & $\begin{array}{c}0.3916^{*} \\
(1.93)\end{array}$ & $\begin{array}{c}0.3082 \\
(1.36)\end{array}$ \\
\hline No. of observation & 2500 & 2500 & 2397 & 2397 & 1732 & 1732 & 1617 & 1617 \\
\hline R-square & 0.918 & 0.918 & 0.915 & 0.916 & 0.893 & 0.894 & 0.895 & 0.896 \\
\hline
\end{tabular}

Note: $* * *, * * *$ significant at the 10 per cen, 5 per cen and 1 per cen levels, respectively. 
Table 4. IT and Inward FDI Stocks, the 1980s vs. the 1990s (with the country-pair fixed effect)

\begin{tabular}{|c|c|c|c|c|c|c|c|c|}
\hline & \multicolumn{4}{|c|}{ 1980-1989 } & \multicolumn{4}{|c|}{$1990-1997$} \\
\hline & $\begin{array}{c}\mathrm{IT}=\text { tele } \\
(1)\end{array}$ & $\begin{array}{c}\mathrm{IT}=\text { tele } \\
(2)\end{array}$ & $\begin{array}{c}\mathrm{IT}=\text { tele }+ \text { cell } \\
\text { (3) }\end{array}$ & $\begin{array}{c}\mathrm{IT}=\text { tele }+ \text { cell } \\
\text { (4) }\end{array}$ & $\begin{array}{c}\mathrm{IT}=\text { tele } \\
(5)\end{array}$ & $\begin{array}{c}\mathrm{IT}=\text { tele } \\
(6)\end{array}$ & $\begin{array}{c}\mathrm{IT}=\text { tele }+ \text { cell } \\
\text { (7) }\end{array}$ & $\begin{array}{c}\mathrm{IT}=\text { tele }+ \text { cell } \\
(8)\end{array}$ \\
\hline $\operatorname{logGDP}_{\mathrm{j}, \mathrm{t}}$ & $\begin{array}{c}0.3987 * * * \\
(2.87)\end{array}$ & $\begin{array}{c}0.3971 * * * \\
(2.87)\end{array}$ & $\begin{array}{c}0.3974 * * \\
(2.55)\end{array}$ & $\begin{array}{c}0.4122^{* *} \\
(2.66)\end{array}$ & $\begin{array}{c}0.4183^{* * * *} \\
(2.92)\end{array}$ & $\begin{array}{c}0.5286^{* * * *} \\
(3.75)\end{array}$ & $\begin{array}{c}0.4727^{* * * *} \\
(3.28)\end{array}$ & $\begin{array}{c}0.5918^{* * * *} \\
(4.05)\end{array}$ \\
\hline $\log \mathrm{GDP}_{\mathrm{i}, \mathrm{t}}$ & $\begin{array}{c}0.6848^{* * * *} \\
(3.42)\end{array}$ & $\begin{array}{c}0.6867 * * * \\
(3.34)\end{array}$ & $\begin{array}{c}0.6891 * * * \\
(3.27)\end{array}$ & $\begin{array}{c}0.6712^{* * *} \\
\quad(3.11)\end{array}$ & $\begin{array}{c}0.0198 \\
(0.06)\end{array}$ & $\begin{array}{c}0.0486 \\
(0.15)\end{array}$ & $\begin{array}{c}0.0672 \\
(0.21)\end{array}$ & $\begin{array}{c}0.1269 \\
(0.41)\end{array}$ \\
\hline $\log I \mathrm{~T}_{\mathrm{i}, \mathrm{t}} * \log \mathrm{IT}_{\mathrm{j}, \mathrm{t}}$ & $\begin{array}{c}0.1221 \\
(1.38)\end{array}$ & $\begin{array}{c}0.1365 \\
(0.67)\end{array}$ & $\begin{array}{c}0.1246 \\
(1.25)\end{array}$ & $\begin{array}{c}0.0038 \\
(0.02)\end{array}$ & $\begin{array}{c}0.1396^{* * * *} \\
(3.65)\end{array}$ & $\begin{array}{c}1.3419 * * * \\
(3.71)\end{array}$ & $\begin{array}{c}0.1194 * * * \\
\quad(2.73)\end{array}$ & $\begin{array}{c}0.8613^{* * * *} \\
(3.59)\end{array}$ \\
\hline $\log I T^{*} \log$ Distance & & $\begin{array}{c}-0.0017 \\
(-0.07)\end{array}$ & & $\begin{array}{c}0.0144 \\
(0.61)\end{array}$ & & $\begin{array}{c}-0.1340 * * * \\
(-3.46)\end{array}$ & & $\begin{array}{c}-0.0795 * * * \\
(-3.27)\end{array}$ \\
\hline openTrade $_{\mathrm{j}, \mathrm{t}}$ & $\begin{array}{c}-0.0022 \\
(-0.40)\end{array}$ & $\begin{array}{c}-0.0022 \\
(-0.41)\end{array}$ & $\begin{array}{l}0.0012 \\
(0.26)\end{array}$ & $\begin{array}{l}0.0015 \\
(0.33)\end{array}$ & $\begin{array}{c}-0.0062 \\
(-1.36)\end{array}$ & $\begin{array}{c}-0.0047 \\
(-1.09)\end{array}$ & $\begin{array}{c}-0.0058 \\
(-1.20)\end{array}$ & $\begin{array}{c}-0.0053 \\
(-1.15)\end{array}$ \\
\hline openFDI $_{\mathrm{j}, \mathrm{t}}$ & $\begin{array}{c}0.0488^{*} \\
(1.83)\end{array}$ & $\begin{array}{c}0.0490^{*} \\
(1.85)\end{array}$ & $\begin{array}{c}0.0979 * * * \\
\quad(2.67)\end{array}$ & $\begin{array}{c}0.0966^{* * * *} \\
(2.70)\end{array}$ & $\begin{array}{l}0.0207 \\
(0.74)\end{array}$ & $\begin{array}{l}0.0123 \\
(0.46)\end{array}$ & $\begin{array}{c}0.0244 \\
(0.85)\end{array}$ & $\begin{array}{l}0.0150 \\
(0.53)\end{array}$ \\
\hline treaty & $\begin{array}{c}-0.3309 * \\
(-1.94)\end{array}$ & $\begin{array}{c}-0.3301 * \\
(-1.91)\end{array}$ & $\begin{array}{c}-0.4825 * * * \\
(-3.65)\end{array}$ & $\begin{array}{c}-0.4896^{* * *} \\
(-3.69)\end{array}$ & $\begin{array}{l}0.9805 \\
(1.45)\end{array}$ & $\begin{array}{l}1.0367 \\
(1.55)\end{array}$ & $\begin{array}{l}1.0041 \\
(1.51)\end{array}$ & $\begin{array}{l}1.0674 \\
(1.63)\end{array}$ \\
\hline NAFTA & & & & & $\begin{array}{c}-0.0943 \\
(-0.45)\end{array}$ & $\begin{array}{c}-0.1500 \\
(-0.66)\end{array}$ & $\begin{array}{c}-0.0677 \\
(-0.31)\end{array}$ & $\begin{array}{c}-0.1421 \\
(-0.55)\end{array}$ \\
\hline \# of observation & 2010 & 2010 & 1792 & 1792 & 2222 & 2222 & 2222 & 2222 \\
\hline R-square & 0.958 & 0.958 & 0.959 & 0.959 & 0.931 & 0.933 & 0.930 & 0.932 \\
\hline
\end{tabular}

Note: $* * *, * * *$ significant at the 10 per cent, 5 per cen and 1 per cen levels, respectively. 
Table 5. IT and Inward FDI Stocks by Distance (IT=teledensity+celldensity)

\begin{tabular}{|c|c|c|c|c|c|c|c|c|}
\hline & \multicolumn{4}{|c|}{ Short-Distance Pair Countries ${ }^{\mathrm{a}}$} & \multicolumn{4}{|c|}{ Long-Distance Pair Countries ${ }^{b}$} \\
\hline & \multicolumn{2}{|c|}{ With host dummy } & \multicolumn{2}{|c|}{ With country pair dummy } & \multicolumn{2}{|c|}{ With host dummy } & \multicolumn{2}{|c|}{ With country pair dummy } \\
\hline $\operatorname{logGDP}, \mathrm{j}, \mathrm{t}$ & $\begin{array}{c}0.5901^{* *} \\
(2.16)\end{array}$ & $\begin{array}{c}0.5961^{* *} \\
(2.19)\end{array}$ & $\begin{array}{c}0.6186^{* * *} \\
(2.22)\end{array}$ & $\begin{array}{c}0.6098^{* * *} \\
(2.20)\end{array}$ & $\begin{array}{c}0.2416 \\
(1.17)\end{array}$ & $\begin{array}{c}0.2640 \\
(1.32)\end{array}$ & $\begin{array}{c}0.5148^{* * * *} \\
(2.70)\end{array}$ & $\begin{array}{c}0.5209^{* * * *} \\
(2.82)\end{array}$ \\
\hline $\log \mathrm{GDP}_{\mathrm{i}, \mathrm{t}}$ & $\begin{array}{c}1.0761^{* * * *} \\
(8.79)\end{array}$ & $\begin{array}{c}1.0690 * * * \\
(8.53)\end{array}$ & $\begin{array}{c}0.1782 \\
(0.35)\end{array}$ & $\begin{array}{c}0.1871 \\
(0.37)\end{array}$ & $\begin{array}{c}1.1930 * * * \\
(15.80)\end{array}$ & $\begin{array}{c}1.2050 * * * \\
(16.19)\end{array}$ & $\begin{array}{c}0.7263 * * * \\
(2.59)\end{array}$ & $\begin{array}{c}0.7598 * * * \\
(2.75)\end{array}$ \\
\hline $\log$ Distance $_{\mathrm{i}-\mathrm{j}}$ & $\begin{array}{c}-1.2750 * * * \\
(-3.91)\end{array}$ & $\begin{array}{c}-1.6034 * * \\
(-1.96)\end{array}$ & & & $\begin{array}{c}-1.1537 * * * \\
(-4.92)\end{array}$ & $\begin{array}{c}-0.3503 \\
(-0.55)\end{array}$ & & \\
\hline $\log \mathrm{IT}_{\mathrm{i}, \mathrm{t}} * \log \mathrm{IT}_{\mathrm{j}, \mathrm{t}}$ & $\begin{array}{c}0.3182 * * * \\
(2.72)\end{array}$ & $\begin{array}{c}0.1436 \\
(0.32)\end{array}$ & $\begin{array}{c}0.3131 * * * \\
(2.89)\end{array}$ & $\begin{array}{c}0.5917 * \\
(1.77)\end{array}$ & $\begin{array}{c}0.3722 * * * \\
(5.15)\end{array}$ & $\begin{array}{c}1.0933 * * \\
(2.36)\end{array}$ & $\begin{array}{c}0.2134 * * * \\
(3.73)\end{array}$ & $\begin{array}{c}1.1051^{*} \\
(1.66)\end{array}$ \\
\hline $\log I T^{*} \log$ Disance & & $\begin{array}{c}0.0216 \\
(0.38)\end{array}$ & & $\begin{array}{c}-0.0339 \\
(-0.89)\end{array}$ & & $\begin{array}{c}-0.0795 \\
(-1.63)\end{array}$ & & $\begin{array}{c}-0.0966 \\
(-1.38)\end{array}$ \\
\hline openTrade $_{\mathrm{j}, \mathrm{t}}$ & $\begin{array}{c}-0.0221^{*} \\
(-1.73)\end{array}$ & $\begin{array}{c}-0.0233^{*} \\
(-1.79)\end{array}$ & $\begin{array}{c}-0.0165 \\
(-1.29)\end{array}$ & $\begin{array}{c}-0.0149 \\
(-1.18)\end{array}$ & $\begin{array}{c}-0.0179 * * * \\
(-3.05)\end{array}$ & $\begin{array}{c}-0.0173 * * * \\
(-2.94)\end{array}$ & $\begin{array}{c}-0.0122 * * \\
(-2.53)\end{array}$ & $\begin{array}{c}-0.0118 * * \\
(-2.43)\end{array}$ \\
\hline openFDI $_{\mathrm{j}, \mathrm{t}}$ & $\begin{array}{c}0.1814^{* *} \\
(2.42)\end{array}$ & $\begin{array}{c}0.1865^{* *} \\
(2.52)\end{array}$ & $\begin{array}{c}0.1580^{* *} \\
(2.05)\end{array}$ & $\begin{array}{c}0.1509^{* *} \\
(2.03)\end{array}$ & $\begin{array}{c}0.0400 \\
(1.40)\end{array}$ & $\begin{array}{c}0.0422 \\
(1.50)\end{array}$ & $\begin{array}{c}0.0603 * * \\
(2.26)\end{array}$ & $\begin{array}{c}0.0601 * * \\
(2.28)\end{array}$ \\
\hline language & $\begin{array}{c}-0.1538 \\
(-0.36)\end{array}$ & $\begin{array}{c}-0.1726 \\
(-0.41)\end{array}$ & & & $\begin{array}{c}0.9139 * * * \\
(3.08)\end{array}$ & $\begin{array}{c}0.9252^{* * * *} \\
\quad(3.13)\end{array}$ & & \\
\hline treaty & $\begin{array}{c}0.4404 * * \\
(2.08)\end{array}$ & $\begin{array}{c}0.4489 * * \\
(2.19)\end{array}$ & $\begin{array}{c}-1.2115^{*} \\
(-1.72)\end{array}$ & $\begin{array}{c}-1.1696^{*} \\
(-1.65)\end{array}$ & $\begin{array}{c}0.6214 * * * \\
\quad(2.70)\end{array}$ & $\begin{array}{c}0.5615^{* *} \\
(2.45)\end{array}$ & $\begin{array}{c}0.3881 \\
(0.93)\end{array}$ & $\begin{array}{c}0.3679 \\
(0.94)\end{array}$ \\
\hline NAFTA & $\begin{array}{c}-0.1008 \\
(-0.45)\end{array}$ & $\begin{array}{c}-0.1214 \\
(-0.55)\end{array}$ & $\begin{array}{r}-0.0355 \\
(-0.13)\end{array}$ & $\begin{array}{c}-0.0068 \\
(-0.02)\end{array}$ & & & & \\
\hline \# of observation & 1522 & 1522 & 1522 & 1522 & 2492 & 2492 & 2492 & 2492 \\
\hline R-square & 0.804 & 0.804 & 0.897 & 0.897 & 0.739 & 0.742 & 0.916 & 0.917 \\
\hline
\end{tabular}

Note: $* * *, * * *$ Significant at the 10 per cent, 5 per cent and 1 per cent levels, respectively. ${ }^{a}$ Distance $<4,722 \mathrm{~km},{ }^{b}$ Distance $>4.722 \mathrm{~km}$.

The average distance between the home and the host countries among the 47 countries under investigation is computed using log Distance $=8.46$ 
of the two countries is less than the average distance of our whole sample, which is $4,722 \mathrm{~km}$, while in columns (5) - (8), the distance is greater than the average distance. All regressions employ the aggregation of teledensity and celldensity as a proxy of the IT variable. When the distance is shorter than the average distance, the elasticity of distance is always negative and significant. After we introduce the interactive term of IT and distance into the regression, the IT variable becomes insignificant and the overall elasticity of distance becomes more negative $(-1.346<-$ 1.275). ${ }^{7}$ On the other hand, when distance is larger than the average distance, the elasticity of distance is not significant with the interactive term and the overall elasticity of distance becomes less negative $(-1.140>-1.154) .{ }^{8}$ In addition, the IT variable turns to be much more significant. These findings suggest that IT becomes more effective in reducing the communication cost and encouraging FDI when the distance between the home and host countries is larger than the average distance, although its marginal impact seems to decrease.

Overall, the IT-augmented gravity model performs quite well in explaining the bilateral FDI activities. All regressions have an R-square above 70 percent. Specifically, the values of R-square are above 90 percent in the regressions with the country-pair fixed effect, which are much higher than the R-squares from the regressions with the host-country fixed effect.

Moreover, almost all of the traditional variables in a gravity equation return expected signs. Both the home and host country's GDP are positive, which indicates the importance of market size for FDI activity. In addition openFDI $I_{j, t}$, is positively related to FDI as expected because the high openness to FDI attracts more international investors. The coefficient of openTrade ${ }_{j, t}$ is negative and significant in most cases, which supports the "tariff-jumping" theory. Language and a bilateral treaty are important determinants for bilateral FDI after controlling for the host-country fixed effect. The evidence for the impact of regional economic integration on FDI are mixed. Although NAFTA seems to encourage FDI from the US and Canada to Mexico according to the sub-sample analysis in Table 3, we do not find integration in Europe to encourage bilateral FDI between member countries. Frankel (1997) gives similar results for bilateral trade between EU

\footnotetext{
${ }^{7}$ The overall elasticity of distance is equal to $\left(-1.6034+0.0216^{*} \log \mathrm{IT}\right)$, where $\log$ IT is mean of $\log \mathrm{IT}$ in the sub-sample.

${ }^{8}$ Similarly, the overall elasticity of distance is equal to $(-0.3503-0.0795 * \log I T)$, where $\operatorname{logIT}$ is the mean of $\log$ IT in the sub-sample.
} 
member countries. Part of the reason is due to the fact that the progress of regional economic integration in Europe has been rather gradual since the Treaty of Rome in 1957, compared with the economic integration in North America, which culminated in mid 1990s. Therefore, our dummy variable for NAFTA captured significant growth of FDI after 1994 while no obvious growth occurred in FDI between EU member countries during the period between 1980 and 1997.

\section{Conclusion}

This paper offer a theory based empirical analysis of the impact of IT on FDI. activities by MNCs. We provided a theoretical justifica-tion for a gravity FDI model, and developed IT-augmented gravity specification for empirical investigation. Applying the IT-augmented gravity model, we found that distance is an important impediment to bilateral FDI due to the high communica-tion cost of sharing information, knowledge and other intangible assets within MNCs. In addition, we provided empirical evidence that the joint development of IT in the home and host countries encourages FDI significantly. Furthermore, an investigation of the interaction term and the total elasticity of FDI with respect to distance confirms that information technology encourages FDI by decreasing the perceived distance between countries. The empirical evidence shows that IT has a more remarkably favorable impact on FDI activities from G7 to OECD countries, compared to nonOECD countries, the impact is more significant the 1990s than the 1980s. Moreover, an investigation of the interaction than between IT and distance and the total elasticity of FDI with respect to distance confirms that IT encourages FDI by decreasing the perceived distance between countries.

The findings in this paper hane important policy implications for the FDI policy in a host country. It is suggested that the development of a modern communication infrastructure should be high on the priority list for countries in order to attract FDI. In addition, the role of multinational headquarters as an informationprocessing center is strengthened with modern communication technology. In other words, multinational firms are better able to disperse operations globally while coordinating and leveraging production and financial management more efficiently over long distances due to the recent development of information technology. 


\section{References}

Blonigen, B. and R. Davis (2000), "The effects of bilateral tax treaties on U.S. FDI activity," NBER Working Paper 7929.

Brainard, Lael (1997), "An empirical assessment of the proximity-concentration trade-off between multinational sales and trade," American Economic Review 87, 520-544.

Carr, D., J. Markusen, and K. Maskus (2001), "Estimating the knowledge-capital model of the multinational enterprises," American Economic Review 91, 693-708.

Ethier, Wilfred (1986), "The multinational firm," The Quarterly Journal of Economics 101, 805-834.

Frankel, Jeffery (1997), "Regional trading blocks in the world economic system," Institute for International Economics, Washington DC.

Harris, Richard (1995), "Trade and communication costs," Canadian Journal of Economics 28, 46-75.

Helpman, E. and Krugman, P. (1985), Market Structure and Foreign Trade, Cambridge: MIT Press.

Kikuchi, Toru (2003), "Interconectivity of communications networks and international trade," Canadian Journal of Economics 36, 155-167.

Kikuchi, T., and T. Ichikawa (2002), "Congestible communications networks and international trade," Canadian Journal of Economics 35, 331-340.

Lipsey, R. and M.Weiss (1984), "Foreign production and exports of individual firms," Review of Economics and Statistics 66, 304-308.

Markusen, James (1984), "Multinationals, multi-plant economics, and the gains from trade," Journal of International Economics 16, 205-226.

Markusen, James (1995), "The boundaries of multinational enterprises and the theory of international trade," Journal of Economic Perspective 9, 169-189.

Markusen, J. and Venables, A. (1998), "Multinational firms and the new trade theory," Journal of International Economics 46, 183-203.

Stone, S. and B. Jeon (2000), "Foreign direct investment and trade in the Asia-Pacific region: complementarity, distance and regional economic integration," Journal of Economic Integration 15:3, 460-485.

Tang, Linghui (2003), "The determinants of international telephone traffic imbalances," Information Economics and policy 15, 127-145. 


\section{Appendix}

\section{Data Discription and Data Sources}

The bilateral FDI statistics used in this study are from the International Direct Investment Statistics Yearbook published annually by the OECD since 1993. Since the data is relatively new, we will discuss it in detail here. The data covers inward and outward FDI flows and stock to (from) OECD countries from (to) the rest of the world. The time period for this database is between 1980 and 1997. The statistics are based mainly on the balance-of-payment data compiled by the central banks or the statistical offices of OECD countries. There are limitations in data comparability due to differences in national definitions. According to the IMF's definition, FDI refers to investments by a resident in another country that lead to 10 percent or more of the ordinary shares or voting power. FDI should have three components: equity capital, reinvested earnings, and inter-company debt. In fact, not all countries have used the 10 percent ownership threshold to define FDI until recent years. The comparability of the FDI data is particularly hampered by the fact that reinvested earnings and inter-company loans were not included in the data for Belgium-Luxemburg and Denmark until 1992, or Greece, Hungary, Japan, Korea, and Portugal until 1996.

In addition, FDI flows are used to estimate missing FDI stocks. Since the FDI statistics between two OECD member countries are reported as FDI inflows by the host country and as outflows by the source country, the inflow and outflow data between the same country pair should be the same in theory. However, due to national differences in FDI definition, currency and statistical errors, they are different most of the time. Nonetheless, the FDI data reported by the host and source countries are highly correlated, with the correlation coefficient above 90 percent. Therefore, we mainly use the FDI data compiled by a host country while using the information reported by a source country to make up missing values.

The GDP, GDP per capita, teledensity, and celldensity data are from the World Telecommunications Indicators published by the International Telecommunications Union. The ratios of a country's imports and inward FDI relative to GDP are from the World Bank's World Development Indicators. The bilateral income and capital tax agreement information is collected from the website of Oceana Publications (www.oceanalaw.com). 